\title{
Study on the Influence of Roadways on Land Plots according to the Results of Monetary Evaluation
}

\begin{abstract}
The paper examines the impact of highways of urban significance on surrounding areas. The authors substantiated the size of the road-effect zone. In order to determine the quantitative extent of the impact of highways on surrounding areas, the scholars applied the data regarding the selling prices of land plots with various designated purpose, i.e. the estimated money value of land is the indicator of determining the road-effect on surrounding areas. Since a great number of factors affects the value of these land plots, in order to determine the road-effect for highways, the authors developed economic and statistical models for expert value of land plots with various designated purpose using the method of multiple regression analysis. After substituting different values of distances to a highway within the road-effect zone in the model, the researchers established the patterns of change in the value of land plots with various designated purpose and calculated the adjustment factors that can be used in the pecuniary valuation of land plots. The value of such coefficients for residential construction land is $0.85-1.00$; for commercial land it is 1.00-1.17; and for industrial land it is 1.00-1.01.
\end{abstract}

Keywords: expert assessment of the monetary, land, economic and statistical model, roadway

Received: 1 November 2020; accepted: 23 December 2020

(C) 2021 Authors. This is an open access publication, which can be used, distributed and reproduced in any medium according to the Creative Commons CC-BY 4.0 License.

1 National University of Water and Environmental Engineering, Educational and Scientific Institute Agroecology and Land Management, Department of Land Management, Cadastre, Land Monitoring and Geoinformatics, Rivne, Ukraine,

email: r.b.shulhan@nuwm.edu.ua, ORCID ID: http://orcid.org/0000-0002-7947-6401

2 National University of Water and Environmental Engineering, Educational and Scientific Institute Agroecology and Land Management, Department of Geodesy and Cartography, Rivne, Ukraine, email: o.e.yanchuk@nuwm.edu.ua, ORCID ID: https://orcid.org/0000-0001-5361-790X

3 National University of Water and Environmental Engineering, Department of Management, Rivne, Ukraine, email: o.v.paharenko@nuwm.edu.ua, ORCID ID: http://orcid.org/0000-0002-5806-7473

4 National University of Water and Environmental Engineering, Department of Ecology, Technology Environment Protection and Forestry, Rivne, Ukraine, email: a.m.pryshchepa@nuwm.edu.ua, ORCID ID: https://orcid.org/0000-0001-5096-9088 


\section{Introduction}

According to the Constitution of Ukraine, land constitutes the main national wealth of the country and is protected by the state [1]. The main principle of the state policy in the field of land protection is based on the priority of the protection of land resources over the potential economic benefits to be obtained. While improving the transport network of the region is of paramount importance, the development of roads is accompanied by concomitant congestion, and thus the impact of the construction and reconstruction of roads on the land of settlements is a burning issue in contemporary environmental protection.

The increase in the urbanization of the population and production has made land in cities a unique resource and the efficiency of its exploitation depends on national economic and social development. Therefore, it is very important to determine the real price of land in order to implement property agreements related to land $[2,3]$.

The practical implementation of land reform, the formation of the land market, and the introduction of the private ownership of land all require clear economic and legal mechanisms for land relation regulation which is based on land evaluation. The functioning of the land market cannot be considered to be effective without the reliable estimation of land.

The research and analysis of relevant factors, especially the influence of roads, together with the implementation of the expert monetary evaluation of land have assumed a critical importance today. The choice of evaluation method depends on the quantity and quality of the initial information about the objects.

There has been a steady annual increase in the volume of road transport in Ukraine despite a number of crises and a trend of population decline. This has led to the road network of cities overloading and has exacerbated the socio-economic, sanitary-hygienic and technical problems associated with people's health, as well as impacting on land resources and the organization of road traffic. The development of road transport is accompanied by two contradictions. On the one hand, achieving a high level of the satisfaction of the needs of the population in vehicles, and, on the other hand, it has increased the negative impact on the environment, especially in cities. In recent years, there are a number of scientific publications that have discussed various aspects of this problem [4-7].

Mechanization brings a variety of benefits to people but the development of the transport network is also accompanied by extremely negative phenomena. Roadways have become a place of death and injury; people are one of the most active polluters of air, water and soil, noise and vibration pollution. The road network passes through cities and villages, and the surrounding fauna and flora suffer from the harmful effects of road transport.

The construction of new highways and the reconstruction of existing ones reduces the value of adjacent lands due to the destruction of the natural landscape, 
road dust, heavy exhaust gases of cars of the vehicles themselves, acoustic noise etc. At the same time, the modernization of the transport network contributes to the sustainable development of the state, so the issue of the impact of the construction of new roads and the reconstruction of existing ones on the cost of adjacent land requires more detailed study. It is well known that the concept of sustainable development includes the need for a safe and healthy environment in establishing a balance between meeting the modern needs of mankind and protecting the interests of future generations [8].

The impact of roads on the surrounding areas is both positive and negative. In our opinion, this problem should be solved using mathematical modelling and multivariate regression analysis with the spatial visualization of the objects of study.

\section{Literature Review}

The pollution and depletion of land resources threaten the health of the population, environmental safety and economic stability of the state. The scientific works of D. Babmindra are devoted to the issue of land condition assessment in Ukraine [9]. Based on the assessment of the state of lands, land resources are managed, as well as their rational use. These issues were studied by V. Horlachuk, V. V'yun, I. Peschans'ka, A. Sokhnych and others [10].

At present, it is obvious that evaluation by traditional methods does not allow to take into account and quantify of subjective factors. To conclude, the procedure needs support using mathematical methods. Regression analysis methods have been widely used in land valuation. Thus, the article [5] describes the features of the application of these methods in solving the problems of site assessment and mass land assessment. In [11], a mathematical model of the expert value of land plots in the city of Rivne was obtained. It makes it possible to determine the average market value and correction factors to the value of the object of evaluation. The main factors influencing the cost of land plots for construction in Rivne have also been identified. The change in the value of the land plot and the change in the value of price-forming indicators are analysed. However, the accuracy of the model is determined.

In recent years, there has been a wide range of work related to the assessment of land status using mathematical modelling and geographic information systems. The emphasis is on taking into account their ecological status. In particular, in [12] the boundaries of natural and agricultural areas were specified by mathematical modelling under conditions of uncertainty and it was proposed the method of automated zoning. This method was tested by monetary valuation of land in different areas.

The article [13] discusses researches and evaluates land in Cyprus. Land valuation is performed using advanced spatial analysis methods, including multiple regression analysis (MRA) and geographically weighted regression (GWR) using geographic information systems (GIS). 
In the work [14] it was determined the size of areas at risk of carbon monoxide pollution derived from road traffic and determining the number of inhabitants exposed to excessive $\mathrm{CO}$ levels using geostatistical modelling on the example of the city of Bydgoszcz, a city in the northern part of Poland. Based on geostatistical modelling, a prediction map of $\mathrm{CO}$ pollution was generated, along with determining the level of $\mathrm{CO}$ concentration. The studies accounted for the variability of road sources as well as the spatial structure of the terrain.

In his papers, Yu. Hubar $[15,16]$ substantiates a comprehensive scientific approach to the valuation of urban lands, while taking into account the urban planning value of the territories. The scholar developed a mathematical algorithm for calculating the cadastral multifactor valuation of the urban area. The researcher proved that the cadastral valuation of urban lands should be represented by a system of integrated indicators, namely, they include economic, environmental and urban planning indicators. Hubar also determined perspective trends with regard to the influence of city-forming factors on the cost of territories. Furthermore, he also developed algorithms and methods of quantitative determination of the price of urban lands.

In turn, Yu. Palekha [17] developed the theoretical and methodological practicalities, as well as methods of economic and geographical study of land value in populated areas. He suggested a method of economic and geographical study of the value of urban areas and their spatial differentiation. The scholar also identified main geographical factors influencing the value formation, he also provided their assessment and carried out the type design of Ukrainian cities. Hence, the methods of regression analysis and GIS-analysis tools provide for effective and reliable determination of the monetary value of land, and therefore research can consider them to determine the impact of certain factors on the land value. The impact of highways on surrounding land plots is one of such factors. The scientists started to study the consequences of the noted impact in 1960's, when the scale of transport development began to affect the environment. A great number of researchers, like I. Yevheniev, B. Karimov, G. Osipov, N. Ivanov, E. Pavlova, V. Ambartsumian, V. Lukanin, Kh. Lents, L. Perovych, R. Vanchura, I. Vaskina and others, were engaged in determining the effect of road transport on humans and the environment, as well as looking for the ways to solve this issue.

Aiming to take into account the impact of road transport on adjacent land plots, O. Yemets' in his paper [7] proposed to consider the pollution of roadside lands by vehicle emissions based on the ratio of the concentration of permissible emissions to the concentration of polluting ingredients in the environment due to transport pollution. In her research article, N. Vnukova [18] states that the impact of the highway (i.e. the road-effect or highway-effect) occurs since its construction. At the stage of operation, the increase in the traffic intensity and speed causes noise, dust, exhaust gases, spills of fuel and lubricants, etc.

It is a well-known fact [19] that highways are threats to ecosystems due to their short- and long-term physical, chemical, and biological effects, therefore the urbanisation of the landscape is obviously the greatest threat to habitat and biota. 
T. Lytvynenko in her paper [20] analysed and structured the highway impact factors on the environment, while K. Szopińska, M. Krajewska and J. Kwiecień in the publication [21] conducted a study of the impact of traffic noise from a busy route on residential property prices using strategic noise map (SNM) resources as a source of real estate information. The housing estate was identified near the Polish city of Bydgoszcz. Assuming that real estate prices reflect its characteristics, the authors tested the following hypothesis: for residential premises located on Kuyavska Street, noise is a characteristic that reduces their price. SNM resources, statistical analysis and econometric modelling were used in the study. Studies have shown that housing prices vary depending on the acoustic zones, but in the surveyed areas is not statistically significant. In addition, the study showed that SNM resources can be a source of information about real estate, especially in the context of environmental factors.

In most of these papers, the scholars view roads/highways as negative effect factor. However, we should note that in many cases, the close location of roads increases the value of land.

In order to study the impact of toll road construction in Orange County, California, on the prices of real estate, M. Boarnet and S. Chalermpong [22] examine the relationship between highways and urban development, using hedonic analysis and sales data. The research shows that homebuyers are willing to pay for better accessibility to land provided by new roads.

In global theory and practice, the problem of land administration and evaluation has been widely reflected. Scientific publications by S. Enemark, I. Williamson, A. Ossro, G. Feder, O. Andras and others, as well as directives of the United Nations and the European Union are devoted to the development of a modern land administration system.

Although, on the one hand, highways worsen the ecological condition of lands, on the other hand, they increase the value of urban lands by improving transport accessibility. Having this in mind, we found a small amount of published research on the highways' impact on adjacent land plots with various designated purposes.

\section{Results}

Bases on the literature review, we established that pecuniary valuation is the result of the integrated impact of rent-forming factors on the valuation object (lands of populated areas). Therefore, in order to identify the impact of roads on such lands, there is a need to analyse the valuation models for lands with various designated purposes.

It is essential to perform a simultaneous assessment of a large group of objects using the tools of economic and mathematical modelling, i.e. mass valuation of land. The bases of this approach are systematic methods of collecting, analysing and processing information to obtain sound results. There are five main stages of mass 
appraisal of real estate: problem statement; preliminary examination and analysis; collection of information, market analysis and finding the options of the best and most profitable use; development and calibration of the model; model testing, quality control and refinement of the obtained results. Figure 1 presents the algorithm scheme for the mass valuation of land resources. Basing on the calculated model, we can obtain adjustment factors to the estimated value of the object, which will take into account the impact of each particular factor [23].

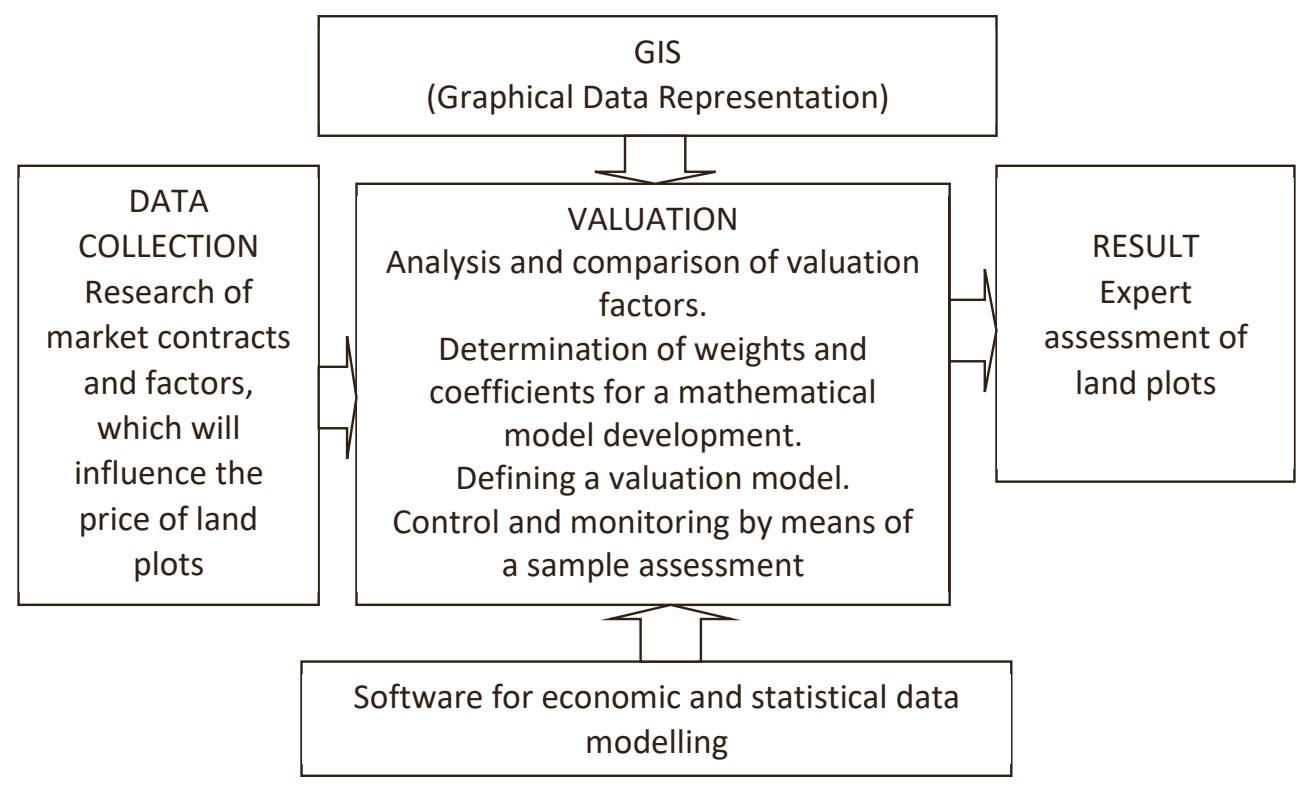

Fig. 1. Algorithm scheme for mass valuation of land resources Source: [23]

The value of land depends on its designated purpose. At the same time, determining the price of land is the key component to creating conditions for economic regulation of land relations, and consequently the management of land resources. Establishing the real value of a land plot is a rather subjective process and depends on many factors, such as its physical characteristics, the form of its ownership and others.

The valuation of land located in populated areas considers the comparative value and suitability of the territory for residential, commercial, and industrial construction and provision of public services and amenities. The noted valuation is based on costs, both with regard to construction and maintenance of buildings, facilities and communications. The experts also have to take into account the engineering and construction characteristics of sites (i.e. land plots), their location on the master plan of the populated area relative to existing buildings, transport connections with 
public, cultural and shopping centers, industrial areas, proximity to existing utilities, environmental conditions, as well as peculiarities of previous use and pollution of the territory. The functional and planning design of the populated areas also effect the pecuniary (monetary) valuation of the lands in these populated areas.

Highways are also one of the important factors influencing the valuation of land plots. The last decades clearly indicate an intensive motorisation process in the society. The concentration of a large number of vehicles in a relatively limited area of the city significantly affects air pollution and, in certain conditions, it leads to the prevailing impact of road transport on the environment.

Roads/highways affect air, soil, water sources and humans by releasing heavy metals and chemical compounds into the atmosphere (carbon monoxide, hydrocarbons, nitrogen oxides, aldehydes, sulphur compounds, particulate matter (carbon soot or smoke), carcinogens, lead compounds, etc.) (Fig. 2), and by creating increased levels of noise, vibration, etc. [24].

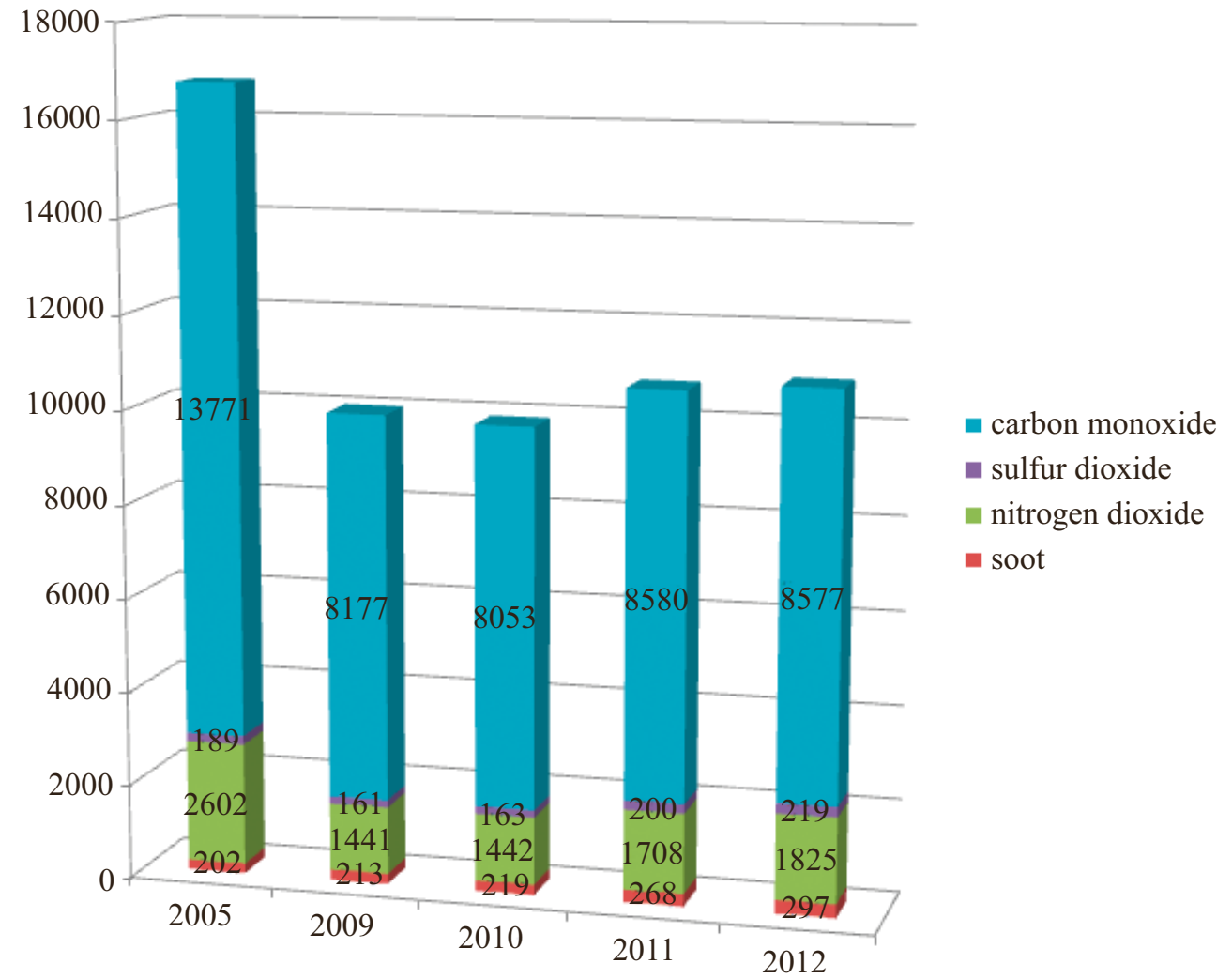

Fig. 2. Emissions of harmful substances into the atmosphere of Rivne from mobile sources [tonnes]

Source: [24] 
Nevertheless, as we mentioned above, a road network, along with the negative impact, has a positive one as well. At the city level, it ensures transport accessibility and improves urban environment. In order to consider all these factors, the practitioners adjust the land value (Fig. 3).

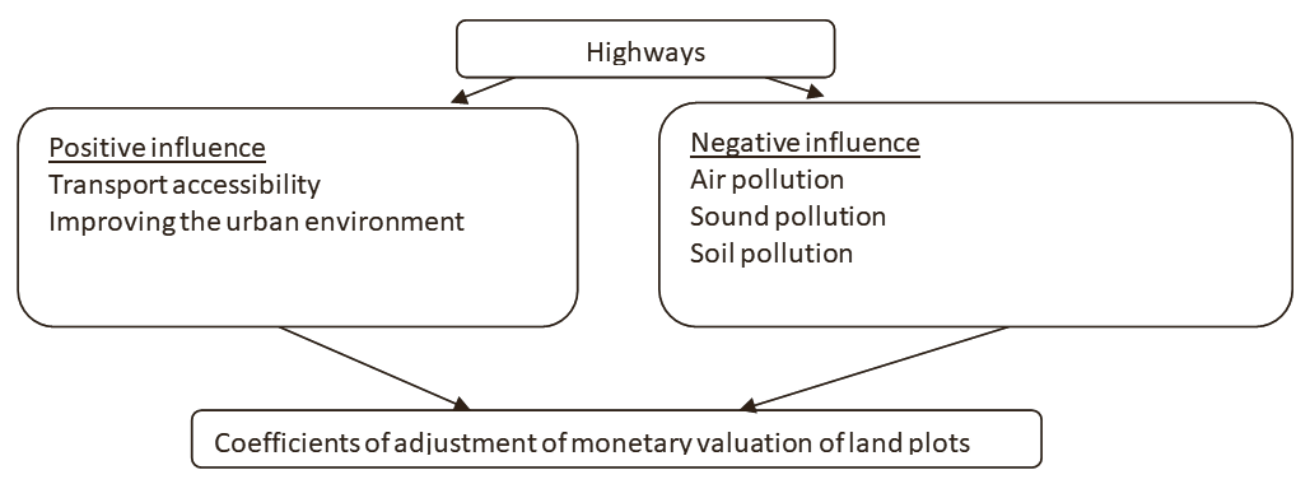

Fig. 3. Road-effect flow chart

With the intention of studying both the positive and negative effects of roads on the surrounding area, we suggest creating mathematical models for expert value of land in Rivne, intended for residential, commercial and industrial construction. This requires the following:

- choosing the factors that affect the expert value of land for the particular designated purpose,

- determining the scales of indicator values with regard to pricing factors,

- developing mathematical models of expert value of land plots by means of multiple regression analysis,

- calculating the change in the value of land plots depending on the change in the indicator values for pricing factors.

The value of land in a market economy depends on the level of its usefulness, consumer properties, and the advantages of land. The main factors influencing the value of land include the following [13, 17, 25-27]: size and configuration, terrain, condition of soils, nature and condition of real estate, location, use of the surrounding area, level of engineering and transport infrastructure, etc. Basing on the comparative analysis of the characteristics of the populated area, we selected the following pricing factors and units of their measurement:

- area $\left[\mathrm{m}^{2}\right]$,

- distance from the centre of the populated area $[\mathrm{km}]$,

- zone of negative impact of highways of urban development significance [points],

- availability of public utilities [points]. 
In order to assess the negative impact of highways, the experts specified a 100-metre-wide sanitary protection zone around them, taking into account the maximum radius of impact on the surrounding areas (Tab. 1) [28].

Table 1. Sizes of sanitary protection zones for highways

\begin{tabular}{|c|c|c|c|c|c||}
\hline \multicolumn{7}{|c||}{ Width of highway sanitary protection zones [m] } \\
\hline air & soil & water & $\begin{array}{c}\text { noise } \\
\text { at 55 dBA }\end{array}$ & $\begin{array}{c}\text { electromagnetic } \\
\text { radiation }\end{array}$ & vibration \\
\hline \hline 85 & 85 & 55 & 100 & 50 & 50 \\
\hline
\end{tabular}

We chose a four-point scale for the factor characterising the negative urban road-effect (Tab. 2). According to this scale, we assigned the appropriate number of points to each road-effect zone (we measured distances from the edge of the roadway). Hence, as the negative effect decreases, the number of points increases.

Table 2. Scale for assessing the urban road-effect for highways of urban development significance

\begin{tabular}{|l|c|c|c|c||}
\hline $\begin{array}{l}\text { Road-effect zone (distance from the highway } \\
\text { of urban development significance) [m] }\end{array}$ & $0-30$ & $31-60$ & $61-100$ & more than 100 \\
\hline \hline Factor values [points] & 1 & 2 & 3 & 4 \\
\hline
\end{tabular}

We assessed the availability of the main types of public utilities on the land plot (i.e. electricity supply, gas supply, water supply, sewerage) using a similar approach (in points) (see Table 3).

Table 3. Scale for assessing the availability of public utilities

\begin{tabular}{|l|c|c|c|c|c||}
\hline $\begin{array}{c}\text { Availability of } \\
\text { public utilities }\end{array}$ & $\begin{array}{c}\text { Power supply } \\
\text { [points] }\end{array}$ & $\begin{array}{c}\text { Gas supply } \\
\text { [points] }\end{array}$ & $\begin{array}{c}\text { Water supply } \\
\text { [points] }\end{array}$ & $\begin{array}{c}\text { Sewerage } \\
\text { [points] }\end{array}$ & Total score \\
\hline \hline Located on site & 3 & 3 & 3 & 3 & 12 \\
\hline Adjacent ones & 2 & 2 & 2 & 2 & 8 \\
\hline Remote ones & 1 & 1 & 1 & 1 & 4 \\
\hline
\end{tabular}

We selected one hundred and fifty-three land plots in Rivne, which had already had an expert monetary evaluation, for research and development of economic and statistical models (Fig. 4). These land plots have different designated functional purposes: fifty-three plots are intended for residential construction, there are fifty commercial sites and fifty industrial sites. They are located in different areas of Rivne. Most land plots are quadrangular in shape, the majority of access roads are paved, but for some land plots there are earth (unpaved) roads, the terrain is flat, the availability of utilities is acceptable. 


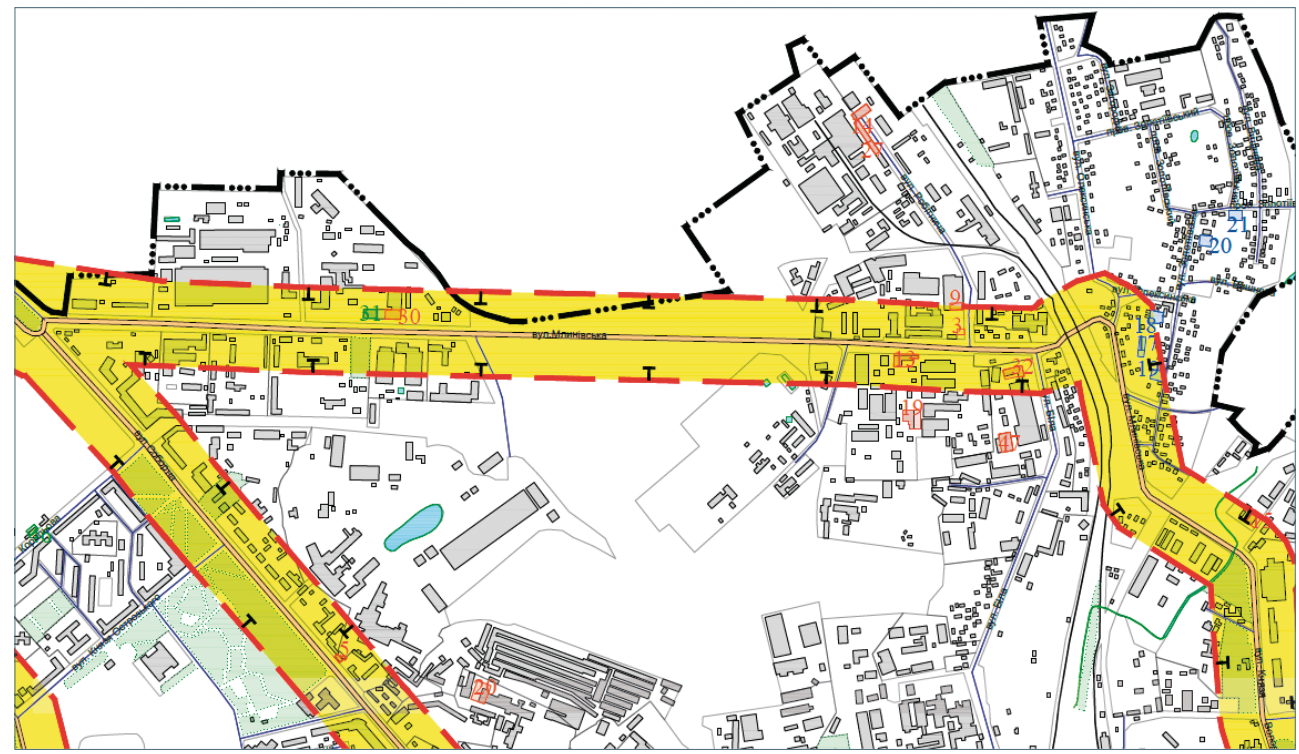

Legend

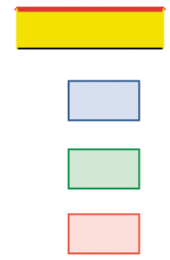

The zone of negative impact of the highway

Land plots are intended for construction of residential house

Commercial land

Land for industrial purposes

Fig. 4. Fragment of the map with the location of land plots

In order to provide a mathematical representation of the value of a land plot we used a linear model of multiple regression (1):

$$
y=a_{0}+a_{1} x_{1}+a_{2} x_{2}+\ldots+a_{n} x_{n}
$$

where:

$$
\begin{aligned}
& y \text { - the average value of the dependent variable, } \\
& x_{1}, x_{2}, \ldots, x_{n}-\text { variables that affect the change in } y, \\
& a_{0}-\text { free unit, } \\
& a_{1}, a_{2}, \ldots, a_{n}-\text { are coefficients demonstrating how much } y \text { increases for each } \\
& \text { one-unit increase in } x .
\end{aligned}
$$

The dependent variable in this model is the selling price for an area unit of a land plot $\left(1 \mathrm{~m}^{2}\right)$. This model allows establishing the dependence of the value of the land on a set of many factors, one of which is the road-effect on surrounding areas. 
After selecting the factors, we identified their numerical values for each of the land plots with regard to their respective designated functional purpose. Explicitly, we determined the area, distance from the centre of the populated area; we assigned the points for the impact of highway of urban development significance, taking into account the distance from the latter one, and points for the availability of utilities. We carried out the measurement of values for evaluation indicators in MapInfo GIS software package (Fig. 5).

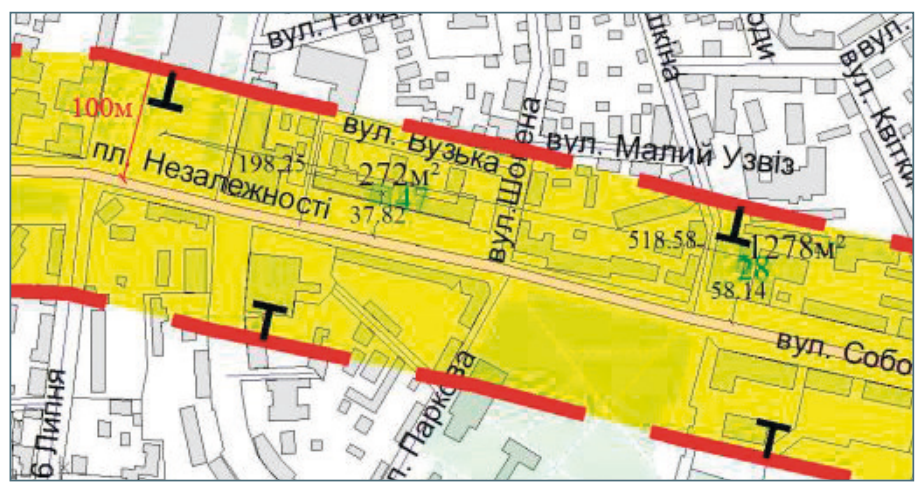

Fig. 5. Exemplary determination of the values for evaluation indicators in MapInfo

After we processed the factor values with the use of Excel by means of the LINEST function, we received the values of coefficients of mathematical models for land plots. Namely, they are as follows:

- for residential construction land:

$$
y=63.2448-0.0237 x_{1}-2.1547 x_{2}+3.2578 x_{3}+2.9478 x_{4}
$$

- for commercial land:

$$
y=107.1523-0.0743 x_{1}-18.0911 x_{2}-9.5956 x_{3}+19.1529 x_{4}
$$

- availability of public utilities for industrial land:

$$
y=62.4984-0.0116 x_{1}-9.8301 x_{2}-0.2264 x_{3}+6.3858 x_{4}
$$

where:

$x_{1}$ - the area $\left[\mathrm{m}^{2}\right]$,

$x_{2}$ - the distance from the centre of the populated area $[\mathrm{km}]$,

$x_{3}$ - the zone of negative impact of highways of urban development significance [points],

$x_{4}$ - the availability of public utilities [points]. 
By virtue of certain models, we established the average values of $1 \mathrm{~m}^{2}$ of land, particularly:

- for residential construction land - 62.04 foreign currency units ${ }^{5}$,

- for commercial land - 180.55 foreign currency units,

- for industrial land - 75.38 foreign currency units.

The procedures of normative monetary valuation of lands in populated area state that when determining the value of land the practitioners should take into account the coefficients that characterise such local factors as: location of land in the area, where construction is restricted according to the degree of air pollution (0.80-0.95), location of land in the area with excess noise from highways (0.90-0.97). The procedures do not specify the possibility of applying the coefficient with regard to air pollution, while taking into account the negative impact of highways. We propose to use it for these purposes as well. This is a decreasing coefficient, as this type of pollution has a negative effect on the surrounding areas and the population. The coefficient that takes into account the acoustic pollution of roads is also a decreasing one due to the fact that this factor negatively affects various systems of the human body.

Aiming to obtain the coefficients for the impact of roads on the value of land, we substitute the average statistical data regarding the area $\left(x_{1 \text { avg }}\right)$, distance from the centre of the populated area $\left(x_{2 \text { avg }}\right)$, the condition of utilities $\left(x_{4 a v g}\right)$, and the maximum score of the factor that takes into account the road-effect on surrounding areas $\left(x_{3 \max }=4\right)$. As a result of calculations, we obtain the average expert value of a land plot $\left(y_{c}\right)$, on which the impact of highways is minimal. Similarly, we set the value of a land plot $y_{i}$, by changing the value of the score according to the road-effect zone: up to $30 \mathrm{~m} x_{3}=1$, from 31 to $60 \mathrm{~m} x_{3}=2$, from 61 to $100 \mathrm{~m} x_{3}=3$ (with the average values of other indicators). Then one can calculate the coefficient for the corresponding zone according to the following equation:

$$
k=y_{i} / y_{c}
$$

Table 4 presents the values of the calculated adjustment factors for the appraised value of land plots with each type of designated purpose, taking into account the impact of highways. Figure 6 graphically visualises the aforementioned data.

Table 4. Calculated coefficients for the impact of highways

\begin{tabular}{||l|l|c|c|c|c||}
\hline \hline \multirow{2}{|c|}{$\begin{array}{c}\text { Zone of negative impact (distance from the highway } \\
\text { of urban development significance) }[\mathrm{m}]\end{array}$} & $\begin{array}{c}1^{\text {st }} \text { strip } \\
(0-30)\end{array}$ & $\begin{array}{c}2^{\text {nd }} \text { strip } \\
(31-60)\end{array}$ & $\begin{array}{c}3^{\text {rd }} \text { strip } \\
(61-100)\end{array}$ & $\begin{array}{c}\text { more than } \\
100\end{array}$ \\
\hline \hline \multirow{2}{*}{$\begin{array}{l}\text { The value of the } \\
\text { coefficient for land } \\
\text { plots }\end{array}$} & for residential construction land & 0.85 & 0.90 & 0.95 & 1.00 \\
\cline { 2 - 7 } & for commercial land & 1.17 & 1.11 & 1.06 & 1.00 \\
\cline { 2 - 6 } & for industrial land & 1.01 & 1.01 & 1.00 & 1.00 \\
\hline
\end{tabular}

\footnotetext{
5 In most cases, the term is used for US dollars.
} 
a)

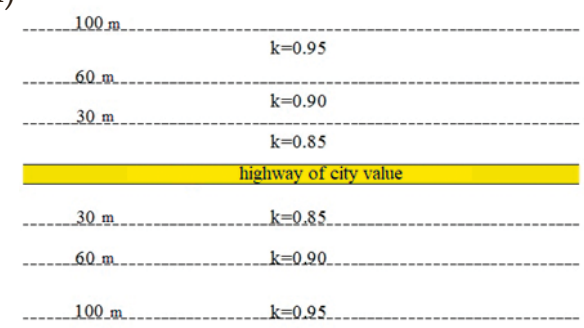

c)

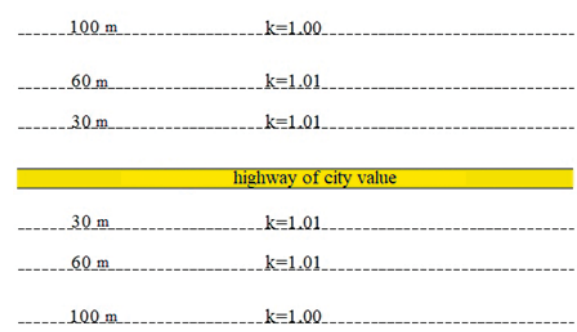

b)

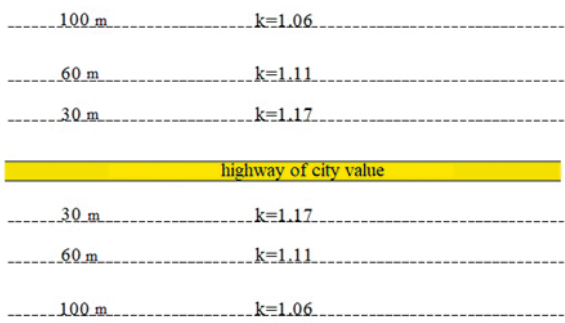

d)

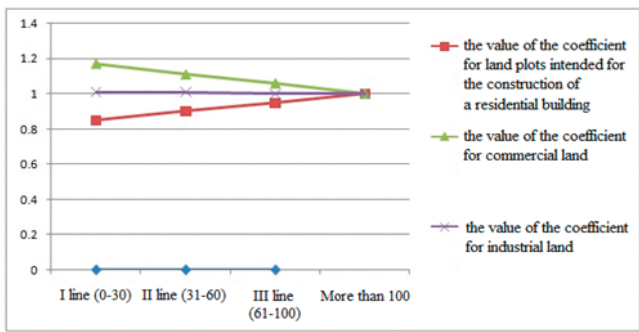

Fig. 6. The layout of the strips' boundaries for the zone of impact of the highway of urban development significance and the corresponding coefficients $k$ for land plots:

for residential construction land (a), for commercial land (b), and for industrial land (c); a dependency diagram between the coefficients adjusting the value of land plots with different designated purposes and the distance to the highway $(\mathrm{d})$

In order to take into account, the road-effect, during the assessment of land plots intended for residential construction, we suggest applying the appropriate value of the coefficient, taking into account the distance of the object to the source of pollution. The coefficient has a decreasing action, because, as we have noted earlier, the impact of this factor is negative for people, soil, etc. For commercial and industrial sites, the adjustment factors are increasing coefficients, as the road network provides good transport accessibility, and, moreover, the location of land plots with this intended use near highways provides good access for consumers and increases the profitability of these land plots as they are easy to find. Therefore, when determining the value of a land plot, the application of these adjustment factors helps to obtain its objective evaluation.

\section{Conclusions}

The conducted research established that the impact of highways on the adjacent territories can be both positive and negative. The study proved that pecuniary (monetary) valuation can be the indicator determining the impact of highways on surrounding land. The experts substantiated a 100-metre-wide road-effect zone and we conducted our research specifically within this indicated area. 
The study used the method of multiple regression analysis in order to determine the impact of highways on the expert value of land plots. The research also included the analysis of the data on the transactions with one hundred and fifty-three land plots with different designated functional purposes located in the city of Rivne.

We developed economic and statistical models for the expert value of land plots intended for residential, commercial and industrial construction. The developed models allow calculating the expert value of land plots with the corresponding designated purpose within the city of Rivne. They became the basis for the study of the impact of highways of urban development significance on the value of adjacent land. Based on them, we calculated the road-effect coefficients. The study established that, for residential construction land, the impact of highways decreases the appraised land value, as transport is a source of negative impact on people and the environment. However, for commercial land, the close location to the highway increases the value or the price of land. This is due to the fact that that good transport accessibility is of paramount importance for these lands. For industrial land, the close location of roads slightly increases their price. The value of the adjustment coefficients for residential construction land equals to $0.85-1.00$; for commercial land it is 1.00-1.17; and for industrial land it is 1.00-1.01.

The achieved results of the study allow the impact of the highway on the pecuniary valuation of land with various designated purposes to be taken into account. The application of the obtained models and coefficients will increase the accuracy and reliability of land valuation in accordance with their location.

\section{References}

[1] Konstytutsiya Ukrayiny. Pravo, Kууіv 1996 [Конституц̧ія Украӥни. Право, Київ 1996].

[2] Land evaluation. Law of Ukraine of 11.12.2003 No. 1378-IV. Date of update: 17.10.2019. https://zakon.rada.gov.ua/laws/show/1378-15 [access: 10.09.2020].

[3] Nikolaychuk K.M.: Udoskonalennya systemy vykorystannya rentoutvoryuyuchykh faktoriv u normatyoniy hroshoviy otsintsi zemel' naselenykh punktiv. Natsional'nyy universytet "L'vivs'ka politekhnika", L'viv 2011 [Ніколайчук K.M.: удосконалення системи використання рентоутворюючих факторів у нормативній грошовій оцінц̧і земель населених пунктів. Національний університет "Львівська політехніка", Львів 2011].

[4] Yerina A.M.: Statystychne modelyuvannya ta prohnozuvannya. KNEU, Kуіv 2001 [Еріна А.М.: Статистичне моделювання та прогнозування. КНЕУ, Київ 2001]. 
[5] Sunderman M.A., Birch J.W.: Valuation of Land Using Regression Analysis. [in:] Wang K., Wolverton M.L. (eds.), Real Estate Valuation Theory, Research Issues in Real Estate, vol. 8, Springer, Boston, MA 2002, pp. 325-339. https://doi.org/10.1007/978-1-4615-0909-7_13.

[6] Vas'kina I.V.: Analiz vplyvu avtotransportnykh zasobiv na navkolyshnye seredovyshche $v$ selitebnykh zonakh mist. Ekolohichna bezpeka, no. 4, 2009, pp. 16-19 [Васькіна І.В.: Аналіз впливу автотранспортних засобів на навколишне середовище в селітебних зонах міст. Екологічна безпека, № 4, 2009, с. 16-19].

[7] Yemets' O.A.: Osoblyvosti otsinyuvannya zemel' dlya potreb dorozhn'oho hospodarstva pry rekonstruktsiyi avtomobil'nykh dorih pid parametry mizhnarodnykh transportnykh korydoriv. Visnyk Natsional'noho universytetu vodnoho hospodarstva ta pryrodokorystuvannya, no. 4(56), pp. 227-232 [Ємець О.А.: Особливості оцінювання земель для потреб дорожнвого господарства при реконструкції автомобільних доріг під параметри міжнародних транспортних коридорів. Вісник Національного університету водного господарства та природокористування, № 4(56), с. 227-232].

[8] Kanash O.P.: Suchasni problem hroshovoyi otsinky zemel' sil's'kohospodars'koho pryznachennya. Zemlevporyadkuvannya, no. 1. 2001, p. 62 [Канаш О.П.: Сyчасні проблеми грошової оцінки земель сільськогосподарського призначення. Землевпорядкування, № 1, 2001, с. 62].

[9] Babmindra D.I.: Vyznachennya ekonomichnoyi otsinky shkody (zbytkiv) vid dehradatsiyi zemel'. Zemlevporyadnyy visnyk, no. 2, 2008, pp. 40-44 [Бабміндра Д.І.: Визначення економічної оцінки шкоди (збитків) від деградації земель. Землевпорядний вісник, № 2, 2008, с. 40-44].

[10] Horlachuk V.V., V'yun V.H., Peschans'ka I.M., Sokhnych A.Ya. et al.: Upravlinnya zemel'nymy resursamy. Mahnoliya, L'viv 2006 [Горлачук В.В., В'юн В.Г., Песчанська I.М., Сохнич А.Я. та ін.: Управління земельними ресурсахи. Магнолія, Аьвів 2006].

[11] Shul'han R.B., Yanchuk O.Ye., Svarytsevych T.M.: Ekspertna hroshova otsinka zemel'nykh dilyanok $z$ vykorystannyam matematychnykh modeley (na prykladi mista Rivne). Visnyk Natsional'noho universytetu vodnoho hospodarstva ta pryrodokorystuvannya. Tekhnichni nauky, no. 4(64), 2013, pp. 330-337 [Шульган Р.Б., Янчук О.Є., Сварицевич Т.М.: Експертна грошова оц̧інка земельних ділянок з використанням математичної моделі (на прикладі міста Рівне). Вісник Національного університету водного господарства та природокористування. Технічні науки, № 4(64), 2013, с. 330-337].

[12] Shulgan R., Kibukevich O., Yanchuk O., Nikolaichuk K.: GRID-model of natural agricultural zoning. Geodesy and Cartography, vol. 43(1), 2017, pp. $22-27$. https://doi.org/10.3846/20296991.2017.1299844.

[13] Demetriou D.: The assessment of land valuation in land consolidation schemes: The need for a new land valuation framework. Land Use Policy, vol. 54, 2016, pp. 487-498. https://doi.org/10.1016/j.landusepol.2016.03.008. 
[14] Kwiecień J., Szopińska K.: Mapping Carbon Monoxide Pollution of Residential Areas in a Polish City. Remote Sensing, vol. 12(18), 2020, art. no. 2885. https://doi.org/10.3390/rs12182885.

[15] Hubar Yu.P.: Kadastrova bahatofaktorna otsinka mis'kykh zemel'. Natsional'nyy universytet "L'vivs'ka politekhnika", L'viv 2004 [Губар Ю.П.: Кадастрова багатофакторна оцінка міських земель. Національний університет “Львівська політехніка", Львів 2004].

[16] Hubar Yu.P.: Zastosuvannya matematychnoho aparatu v metodychnomu pidkhodi, shcho gruntuyet'sya na zistavlenni tsin na prodazh podibnykh zemel'nykh dilyanok. Heodeziya, kartohrafiya ta aerofotoznimannia, no. 69, 2007, pp. 157-163 [Губар Ю.П.: Застосування математичного апарате в методичному підході, що ьрунтуеться на зіставленні цін продажу подібних земельних ділянок. Геодезія, картографія и аерофотознімання, № 69, 2007, pp. 167-163].

[17] Palekha Yu.M.: Ekonomiko-heohrafichni aspekty formuvannya vartosti terytoriy naselenykh punktiv. Profi, Kууіv [Палеха Ю.М.: Економіко-географічні аспекти формування вартості територій населених пунктів. Профі, Київ 2006].

[18] Vnukova N.V.: Vplyv avtomobil'nykh dorih na ekobezpeku kompleksu «avtomobil'doroha-seredovyshche». Vostochno-Yevropeyskiy zhurnal peredovykh tekhnologiy, no. 5/3(53), 2011, pp. 43-46 [Внукова Н.В.: Вплив автомобільних доріг на екобезпеку комплексу «автомобіль-дорога-середовище». Восточно-Европейский журнал передовых технологий, № 5/3(53), 2011, с. 43-46.

[19] Wheeler A.P., Angermeier P.L., Rosenberger A.E.: Impacts of New Highways and Subsequent Landscape Urbanization on Stream Habitat and Biota. Reviews in Fisheries Science, vol. 13, issue 3, 2005, pp. 141-164. https://doi. org/10.1080/10641260590964449.

[20] Lytvynenko T.P.: Ekolohichni pryntsypy proektuvannya avtomobil'nykh dorih. Zbirnyk naukovykh prats' Poltavs'koho natsional'noho tekhnichnoho universytetu im. Yu. Kondratyuka. Haluzeve mashynobuduvannya, budivnytstvo, no. 4(2), 2013, pр. 122-131 [Дитвиненко Т.П.: Екологічні принцципи проектування автомобільних доріг. Збірник наукових праць Полтавського національного технічного університету ім. Ю. Кондратюка. Галузеве машинобудування, будівництво, № 4(2), 2013, с. 122-131]. http://nbuv. gov.ua/UJRN/Znpgmb_2013_4(2)_18 [access: 10.09.2020].

[21] Szopińska K., Krajewska M., Kwiecien' J.: The Impact of Road Traffic Noise on Housing Prices - Case Study in Poland. Real Estate Management and Valuation, vol. 28, issue 2, 2020, pp. 21-36.

[22] Boarnet M.G., Chalermpong S.: New highways, house prices, and Urban development: A case study of toll roads in orange county, Ca. Housing Policy Debate, vol. 12, issue 3, 2001, pp. 575-605. https://doi.org/10.1080/10511482.2001. 9521419. 
[23] Drapikovs'kyy O.I., Ivanova I.B.: Masova otsinka mis'kykh zemel': Ukrayina ta svitovyy dosvid. Visnyk Prydniprovs'koyi derzhavnoyi akademiyi budivnytstva ta arkhitektury, no. 6/7, 2009, pp. 36-42 [Драпіковський О.І., Іванова І.Б.: Масова оцінка міських земель: Украйна та світовий досвід. Вісник Придніпровської державної академії будівництва та архітектури, № 6/7, 2009, c. 36-42].

[24] Profile of the community of Rivne. http://www.city-adm.rv.ua/RivnePortal/ ukr/gromada_profile.aspx [access: 11.09.2020].

[25] Expert monetary valuation of land plots. Methods of expert monetary valuation of land. Resolution of the Cabinet of Ministers of October 11, 2002 No. 1531. https://zakon.rada.gov.ua/laws/show/1531-2002-\%D0\%BF [access: 11.09.2020].

[26] Kryvobokov M.H.: Vybir faktoriv vartosti mis'kykh zemel' ta yikhnikh pitomuh vah dlya rozrakhunku zonal'noho koefitsiyenta. Zemlevporyadnyy visnyk, no. 2, 2003, pp. 77-81 [Кривобоков М.Г.: Вибір факторів вартості міських земель та їхніх питомих ваг для розрахунку зонального коефіцієнта. Землевпорядний вісник, № 2, 2003, с. 77-81]

[27] The statement of the Procedure for carrying out expert monetary assessment of the land plots. Order of the State Committee of Ukraine for Land Resources of 09.01.2003 No. 2. https://zakon.rada.gov.ua/laws/show/z0396-03 [access: 12.09.2020].

[28] Order of the Ministry of Health of Ukraine dated 19.06.1996 No. 173. http:// zakon2.rada.gov.ua/laws/show/z0379-96/page [access: 12.09.2020]. 